\title{
胸部外科手術における術後心房細動
}

\section{横田 泰佑}

\begin{abstract}
要約：ICUにおいて, 新規発症の心房細動は一般的な合併症である。特に心臓手術の術後心 房細動 (postoperative atrial fibrillation, POAF) の発生率は高い。しかし, 心臓手術と比較して, 心臓手術を除くPOAFに対する情報は十分ではない。各々の手術でPOAFは術後 2 日目に発 症しやすい傾向にあり，POAFにより入院日数が延長し，死亡率が増加する。予防的薬剤は POAFを効果的に減少させる可能性がある。POAF発症後は，レートコントロールまたはリ ズムコントロールが行われるが, これらの治療が実際に有効かどうかは不明である。周術期 管理を行う際は，肺切除術では術式によりPOAFの発生率が異なるため注意する。術前から スタチンと $\beta$ 遮断薬を内服していた患者では内服を継続し，血清マグネシウム濃度が低い場 合は，マグネシウム製剤の補充を考慮する。POAFの定義自体が各研究により異なり，不明 な点は多い。本稿では, 主に肺切除術, 食道切除術, 肺移植術のPOAFの疫学, 危険因子, 予防法, 治療法について解説する。
\end{abstract}

Key words: (1) new-onset atrial fibrillation, (2) postoperative atrial fibrillation, (3) epidemiology, (4) risk factors, (5) non-cardiac surgery

\section{I .はじめに}

ICUに扔いて, 心房細動 (atrial fibrillation, Af)の既 往がない患者の, 新規発症の心房細動 (new-onset Af) は一般的な合併症である。心臟手術 (人工心肺を用い る大血管手術などを含む)を除く ICU患者の new-onset Afの発生率は5〜15\%である1)。Afは心 房（近接した肺静脈, 上大静脈, 冠静脈なども含む)の 構造的異常や電気生理学的異常またはその組み合わせ により発生し, 自律神経系などの外因性の要因も多く の場合で関与している。しかし, その発症メカニズム は完全には解明されていない2)。

一方, 心臟手術では, 術後心房細動 (postoperative atrial fibrillation, POAF) の発生率は $30 \sim 50 \%$ と高 い。その発症に関するメカニズムは, 外科的心房傷害, 心房虚血, 肺静脈孔, 静脈カニュレーション, 急性の 容量変化などの手術因子と, 容量過多, 低血圧, 後負 荷増加などの術後因子と, 心房性期外収縮, 電解質不 均衡, 自律神経系の不均衡などのトリガー因子が関与
しており, それらの術後の一過性の複数の因子が関与 している点が他の Af と異なる3)。

胸部外科手術 (肺切除術と食道切除術を含み, 心臟 手術を除く)では, 交感神経刺激や心房拡張などが卜 リガー因子となるが, 正確な発症メカニズムは解明さ れていない4)。心臟手術と胸部外科手術以外の POAF については, 電解質異常などの患者因子や術後疼痛な どにより交感神経が活性化することがトリガー因子に なってPOAFが発症する。しかしながら, その発症义 カニズムもおそらく多因子であり, 完全には解明され ていない5)。

心臟手術の周術期のPOAFに関して多くの研究や ガイドラインが存在する6) 8)。一方, 周術期に POAFを認める場合, 非心臟手術の方が心臟手術と比 較して慢性期の脳卒中の発生率が有意に高かった, と いう報告があるにもかかわらず9)，非心臟手術後にお けるAfについての報告は少ない。そのため, 本稿で は心臟手術を除くPOAFに対して, 比較的発生率の高 い胸部外科手術を中心に, 疫学, 危険因子, 予防法, 治 療法について解説する。 


\section{II. 肺切除術}

\section{1) 疫学}

肺切除術のPOAFの発生率は, 術式により異なる。 肺部分切除術後では $2 \sim 4 \%$ と低く, 肺葉切除術後で は10～15\%，全肺切除術後では $20 ３ 0 \%$ と高い 10$) 。$ また, 全肺切除術では, 手術時間の長い患者の方が心 調律異常 ‘Af と心房粗動 (atrial flutter, AF) が6割程 度了の発症が有意に高く，その心調律異常を発症した 患者で死亡率が有意に高い11)。POAFは，術式にか かわらず発生日が肺切除術後2 日目をピークとするも のが多く12), POAFにより入院日数が延長し，コスト が増加する13)。また, 肺葉切除術後に発症する上室 性頻拍（AfとAFを含む）により脳卒中 (OR 1.74, $95 \%$ CI $1.03 \sim 2.94)$, 院内死亡率 (OR $1.85,95 \%$ CI $1.45 \sim 2.35)$, 入院日数 $(\mathrm{OR} 1.33,95 \% \mathrm{CI} 1.29$ ～ 1.37), 30 日以内の再入院 (OR 1.29, $95 \%$ CI 1.04 1.60) が増加することが指摘されている14)。POAFを 発症した患者の 3 分の 1 は, 持続性心房細動になるか, または治療介入が必要になる15)。

\section{2) 危険因子}

危険因子としては, 高齢者, 男性, 前胸部横断切開 法 (clamshell incision), 右肺切除術, 再吻合術, 虚血 性心疾患の既往, 心不全, 術中心停止, 過度の飲酒, 赤 血球輸血, 強心薬などが挙げられる13),16),17)。ただし， 胸腔鏡下手術と比較して開胸手術が危険因子としてい る報告がある一方で 16$)$, 胸腔鏡下肺葉切除術では開胸 手術と比較してPOAFの発生率に差はない, と報告し ている研究もあり 18 ，今後の研究が待たれる。また， 胸部外科手術のPOAFに関するガイドライン4)では, その他に高血圧, 心筋梗塞, 弁膜性心疾患, 肥満, 閉塞 性睡眠時無呼吸症候群, 喫煙, 甲状腺機能克進症, 左 室肥大, 家族歴, 不整脈の既往なども危険因子に挙げ られているが, 肺切除術単独の研究に基づいていない ことを留意すべきである。

\section{3）予防法}

Riber ら ${ }^{19)}$ は, 肺切除術後に関する 10 研究のメ夕解 析を行った。予防的薬剤として,アミオダロン, $\beta$ 遮 断薬, カルシウム $(\mathrm{Ca})$ 拮抗薬, ジゴキシン, マグネシ ウム $(\mathrm{Mg})$ 製剤が使用された。その結果, ジゴキシン 以外の薬剤で予防効果があり，特にアミオダロンが最 も有効で, POAFを $30 \%$ から約 $10 \%$ に有意に減少さ せた。また, 副作用 (低血圧と徐脈)に関して,アミオ ダロンと $\mathrm{Mg}$ 製剤で発生率が低かった。 $\mathrm{Mg}$ 製郕に関 して, 胸部外科手術において, Afを含む上室性不整脈
に対して予防効果はなかった，とも報告されてい る20)。しかし, ICUに扔いて血清 Mg濃度が低い場合, 死亡リスクが増加する（OR 1.85, 95\%CI 1.31～2.60) ことが報告されており，Afの有無にかかわらず, ICU では低 $\mathrm{Mg}$ 血症の患者には, $\mathrm{Mg}$ 製剤の補充を考慮す るべきである211。

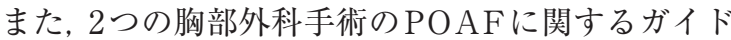
ラインによると ${ }^{4), 222}$, 術前から内服していた $\beta$ 遮断薬 を急激に中止すると POAFの危険性が高まるため, 術 後も継続することを推奨クラス I としている。一方で, 新規に予防的に $\beta$ 遮断薬であるアセブトロールおよ びジルチアゼムとプラセボを投与した群を比較した前 向き無作為化比較試験では, POAFの発生率に統計学 的な有意差は認めていない23)。同様に, Aoyamaら 24) は, 本邦で使用可能な $\beta$ 遮断薬であるランジオロール において, 二重盲検ランダム化比較試験を行った。結 果として, 術中にランジオロールを持続静注した群と プラセボ群では, 肺切除術後のPOAFの発生率に有意 差を認めなかった。

ホスホジエステラーゼ (phosphodiesterase, PDE) III 阻害薬のシロスタゾールは, 心房伝導時間を短縮さ せAf発症予防につながる可能性がある25)。Nojiri ら 26) は, 本邦で使用可能な PDE II 阻害薬であるオルプリ ノンに関して, 術前にB 型ナトリウム利尿ペプチド高 值を認めた 40 人の患者に対して,オルプリノン持続 静注の二重盲検ランダム化比較試験を行った。結果, オルプリノン投与群はプラセボ群に比較して有意に POAFの発生率が低かった $(10 \%$ vs. $60 \%)$ 。さらに, 胸部外科手術に関する研究で, スタチンを内服してい た患者では有意にPOAFの発生率が低くなることが 示されている $(\mathrm{OR} 0.26,95 \% \mathrm{CI} 0.08 \sim 0.82) 27)$ 。以上 のことから，予防的薬剤をルーチンで投与する必要が あるかどうかは現時点では不明のため, 今後の研究が 待たれる。

\section{4) 治療法}

$\mathrm{POAF}$ の治療に関して, 前述した $2 つ の$ 胸部外科手 術のPOAFに関するガイドラインによると4),22)，レー トコントロールには $\beta$ 遮断薬か $\mathrm{Ca}$ 拮抗薬が推奨さ れ，血行動態が不安定，または抗不整脈薬によるリズ ムコントロールが不成功の場合は, 電気的除細動が推 奨されている。しかし，心臟手術に関する研究ではあ るが, レートコントロールとリズムコントロールでは 合併症の発生率や死亡率に差がなかったことが報告さ れている8)。 


\section{III. 食道切除術}

\section{1) 疫学}

食道切除術のPOAFの発生率は 8 26\%で 28) 35), 多くは食道切除術後 $2 \sim 3$ 日目以内に発症する 30 )。 POAFを発症すると合併症 (肺合併症, 縫合不全, 敗 血症など) と死亡率が増加するが28),301,31),34)，研究自体 が後ろ向き観察研究のためか, 合併症が重篤のために 死亡率が増加した可能性がある。そのため, POAFに より合併症と入院日数の延長と死亡率は増加しない,

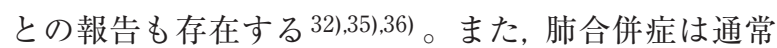
$\mathrm{Af}$ の発生と同時期に起こるが, 縫合不全は平均で Af 発症の 4 日後に診断される 30 )。

\section{2) 危険因子}

危険因子として, 高齢者, 男性, 慢性閉塞性肺疾患, 心疾患, 高血圧, 糖尿病, B型ナトリウム利尿ペプチ ド高值, 術後低酸素血症, 術前補助療法, 術後の胸部 胃拡張, 再建手術での結晹導管の使用, 術後1日目の 心拍数が $100 / \mathrm{min}$ 以上, などが挙げられる 29,31) 36)。 Chin ら ${ }^{34)}$ は, 後ろ向き観察研究で, 術前のCa拮 抗薬とアンジオテンシン変換酵素 (angiotensin converting enzyme, ACE) 阻害薬とアンジオテンシン II 受容体拮抗薬 (angiotensin II receptor blocker, $\mathrm{ARB})$ の内服も危険因子として報告している。房室伝 導結節を抑制する非ジヒドロピリジン系 Ca 拮抗薬と, 心房リモデリングを抑制する ACE 阻害薬と ARBに関 しては, Af発症を抑制する方向に働くと考えられるた め, 薬剤そのものではなく, 何らかの患者因子が原因 と考えられる。ただし, 術前にCa拮抗薬, ACE 阻害薬, $\mathrm{ARB}$ のいずれかの内服をしている患者は, POAFの 発症の危険性があることを念頭に置く必要がある。ま た，上室性頻脈性不整脈の研究ではあるが, 周術期の テオフィリンの使用, 術前の一酸化炭素肺拡散能低值, 発熱，アドレナリンの使用が危険因子として指摘され ている37,38)。前述した胸部外科手術のPOAFに関す るガイドライン4)より, 甲状腺機能立進症などの危険 因子が挙げられるが,「II．肺切除術」で記載したのと 同様に, 食道切除術単独の研究ではないことを留意す ベきである。

\section{3) 予防法}

Tisdale ら ${ }^{39)}$ は, 胸腔鏡下食道切除術を受けた患者 80 人を, 麻酔導入時から予防的にアミオダロンを投与 した群とプラセボ群を前向きに無作為に割り付けし た。結果, アミオダロン投与群では, 有意にPOAFの 発生率が低かった $(15 \%$ vs. $40 \%)$ が, 入院日数, ICU
滞在時間, 術後合併症に有意差はなかった。肺切除術 と同様に, 食道切除術に打いても $\beta$ 遮断薬であるラン ジオロールに関して研究が行われた。麻酔導入時から ランジオロールを持続静注した群とプラセボ群を対照 としたランダム化比較試験において, ランジオロール 投与群の方が有意にPOAFの発生率が低かった $(5.3 \%$ vs. 35\%) 40)。同じく, 術前からランジオロールを持 続静注した群とプラセボ群を対照とした二重盲検ラン ダム化比較試験においても, ランジオロール投与群の 方が有意にPOAFの発生率が低かった（10％vs. $30 \%) 41$ 。Ca拮抗薬, ジゴキシン, $\mathrm{Mg}$ 製剤に関しては, 前述の肺切除術の予防法と同様であり, 予防的薬剤を ルーチンで投与する必要があるかどうかは現時点では 不明である。

POAFの治療法は, 前述の肺切除術の場合と同様で ある。

\section{IV ． 肺移植術}

本邦では, 1988年から生体肺移植が始まったが, 肺 移植認定施設は 2016 年 10 月時点で 9 つしかい 42$) 。$ そのため, 肺移植の術後管理に携わる機会は少ないと 思われるが, 肺移植術のみを対象にした研究が散見さ れるため, 疫学と危険因子について記す。

\section{1) 疫学}

肺移植術のPOAFの発生率は16～39\%であり 43) 48), 肺移植術後 2 日目に最も多く発症する ${ }^{44)}$ 。また, 手術

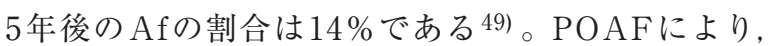
肺炎などの合併症や気管切開術の施行が起きやすくな り, 入院日数が延長し, 死亡率が増加する ${ }^{43)}$ 。一方で, 食道切除術と同様に後乃向き観察研究のためか, 死亡

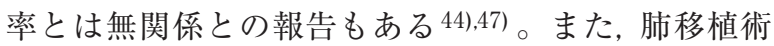
後の心房頻拍は, 術後 1 年以上経過してから発症する 患者の割合が最も多い，との研究がある50)。

\section{2) 危険因子}

危険因子として, 高齢者, 特発性肺線維症, 心疾患, 左心房の拡大, 術後の昇圧薬の使用, 原発性肺高血圧, 肥満・るいそう，両肺移植などが挙げられる 43,44),47)。 一方で, 肺動脈収縮期圧が $10 \mathrm{mmHg}$ 上昇するごとに, POAFのオッズ比を $31 \%$ 減少させる $(\mathrm{OR}$ 0.69, 95\% CI $0.49 \sim 0.98)$ 48) とも報告されており, POAFの正確な メカニズムは不明なままである。

\section{V ．その他の手術}

心臓手術と胸部外科手術以外の手術に扮ける 
Table 1 Incidence of postoperative atrial fibrillation in non-cardiac surgery

\begin{tabular}{lr}
\hline \hline Single wedge resection & $2.0 \sim 4.0 \%$ \\
Lobectomy & $10.0 \sim 15.0 \%$ \\
Pneumonectomy & $20.0 \sim 30.0 \%$ \\
Lung transplantation & $16.0 \sim 39.0 \%$ \\
Esophagectomy & $7.7 \sim 25.6 \%$ \\
Vascular surgery & $4.7 \sim 10.0 \%$ \\
Gastrectomy & $8.1 \%$ \\
Radical cystectomy & $1.9 \sim 8.0 \%$ \\
Trauma & $5.5 \%$ \\
\hline
\end{tabular}

POAFの発生率は約 $0.4 \%$ で, 多くは術後 2 日目に発症 し, 高齢者と緊急手術が危険因子であり, POAFによ り入院日数が延長し, 死亡率が増加する51),52)。心臓 手術と胸部外科手術以外の手術でのPOAFの発生率 は稀であるが, $10 \%$ の患者で心房性不整脈が発症す る53)，と報告されている。

POAFの発生率は, 血管外科手術 (人工心肺を用い る大血管手術などを除く)で5\%, 胃切除術で $8 \%$, 根 治的膀胱摘除術で 2 ～ $8 \%$ であり，いずれも急性心筋 梗塞および脳卒中などの心血管イベントの危険因子で ある 54) 56)。一方, open surgeryによる大動脈瘤手 術に限ると, POAFの発生率は $10 \%$ であり, ICUの滞 在期間と入院日数および死亡率は, POAFが発症した 患者とそれ以外の患者で差はない57)。

また，必ずしも術後とは限らないが, surgical ICU に入室した外傷患者の Afの発生率は約 $6 \%$ であり 58 , 鈍的胸部外傷がPOAFの危険因子と報告されてい る59)

\section{VI. 周術期管理}

周術期管理としては，肺切除術では手術方法により POAFの発生率が異なる (Table 1) ため, 予定術式と 変更がないかどうかを外科医に確認する。術前からス タチンと $\beta$ 遮断薬を内服していた患者では内服を継 続し, 血清 $\mathrm{Mg}$ 濃度が低い場合は, $\mathrm{Mg}$ 製剤の補充を考 慮する。各々の手術でPOAFは術後 2 日目に発生しや すい傾向にある。

POAFが実際に発生した場合は，各手術に対応する 治療法は前述した通りである。筆者は, 術式にかかわ らず，まずリズムコントロールを試みるが，心拍数 $110 / \min$ 以上の場合 ${ }^{60)}$, 循環動態が安定している症 例ではレートコントロールを行っている。

POAFが48時間以上継続する場合，出血の危険が
高くなければ, 脳梗塞予防にワルファリンか新規経口 抗凝固薬による抗凝固療法を検討する。また, 人工弁 置換術後患者ではヘパリンブリッジが推奨されてい る2)。ただし, $\mathrm{CHA}_{2} \mathrm{DS}_{2}-\mathrm{VASc}$ スコア ${ }^{61)}$ が1点以上 の場合は, POAF発症 48 時間以内に抗凝固療法の開 始を考慮する。術後洞調律に復帰後も, 左心房の機能 低下 (stunning) が持続するため, 抗凝固療法は 4 週間 程度継続する4)。

\section{VII. 最後に}

前述した胸部外科ガイドラインでは, 心電図上 30 秒 以上続くものをPOAF と定義しているが4), そもそも 定義自体が各研究により異なっており, 不明な点は多 い。また,Afの治療に関して, Shaverら ${ }^{62)} は, 2$ 日以 上ICUに入室した患者 1,770 人 (心臓手術と外傷患者 を除く)を対象にコホート研究を行った。結果，Afを 治療した群と非治療群では院内死亡率に有意差を認め なかった $(29 \%$ vs. $34 \%) 。$

しかし，心臓手術以外も POAFに関してさまざまな 知見が得られており, ICU管理を行う上で各手術の疫 学や危険因子を把握し, 必要に応じて治療介入を行う べきであろう。

本稿の著者には規定されたCOIはない。

\section{文 献}

1) Yoshida T, Fujii T, Uchino S, et al. Epidemiology. prevention, and treatment of new-onset atrial fibrillation in critically ill: a systematic review. J Intensive Care 2015;3:19.

2) January CT, Wann LS, Alpert JS, et al; ACC/AHA Task Force Members. 2014 AHA/ACC/HRS guideline for the management of patients with atrial fibrillation: a report of the American College of Cardiology/American Heart Association Task Force on practice guidelines and the Heart Rhythm Society. Circulation 2014;130:e199-267.

3) Echahidi N, Pibarot P, O'Hara G, et al. Mechanisms, prevention, and treatment of atrial fibrillation after cardiac surgery. J Am Coll Cardiol 2008;51:793-801.

4) Frendl G, Sodickson AC, Chung MK, et al; American Association for Thoracic Surgery. 2014 AATS guidelines for the prevention and management of perioperative atrial fibrillation and flutter for thoracic surgical procedures. J Thorac Cardiovasc Surg 2014;148:e153-93.

5) Joshi KK, Tiru M, Chin T, et al. Postoperative atrial fibrillation in patients undergoing non-cardiac non-thoracic surgery: A practical approach for the hospitalist. Hosp Pract (1995) 2015:43:235-44.

6) Mathew JP, Fontes ML, Tudor IC, et al; Investigators of the Ischemia Research and Education Foundation; Multicenter Study of Perioperative Ischemia Research Group. A multicenter risk index for atrial fibrillation after 
cardiac surgery. JAMA 2004;291:1720-9.

7) Halonen J, Halonen P, Järvinen O, et al. Corticosteroids for the prevention of atrial fibrillation after cardiac surgery: a randomized controlled trial. JAMA 2007;297: $1562-7$.

8) Gillinov AM, Bagiella E, Moskowitz AJ, et al; CTSN. Rate Control versus Rhythm Control for Atrial Fibrillation after Cardiac Surgery. N Engl J Med 2016;374:1911-21.

9) Gialdini G, Nearing K, Bhave PD, et al. Perioperative atrial fibrillation and the long-term risk of ischemic stroke. JAMA 2014;312:616-22.

10) Shrivastava V, Nyawo B, Dunning J, et al. Is there a role for prophylaxis against atrial fibrillation for patients undergoing lung surgery? Interact Cardiovasc Thorac Surg 2004;3:656-62.

11) Foroulis CN, Kotoulas C, Lachanas H, et al. Factors associated with cardiac rhythm disturbances in the early post-pneumonectomy period: a study on 259 pneumonectomies. Eur J Cardiothorac Surg 2003;23:384-9.

12) 沖田寿一, 宇治満喜子, 新城武明, 他. 肺切除手術後の心 房細動発症に及ぼす塩酸ランジオロールの影響. 麻酔 2008;57:953-8

13) Roselli EE, Murthy SC, Rice TW, et al. Atrial fibrillation complicating lung cancer resection. J Thorac Cardiovasc Surg 2005;130:438-44.

14) Giambrone GP, Wu X, Gaber-Baylis LK, et al. Incidence and implications of postoperative supraventricular tachycardia after pulmonary lobectomy. J Thorac Cardiovasc Surg 2016;151:982-8.

15) Ivanovic J, Maziak DE, Ramzan S, et al. Incidence, severity and perioperative risk factors for atrial fibrillation following pulmonary resection. Interact Cardiovasc Thorac Surg 2014;18:340-6.

16) Dyszkiewicz W, Skrzypczak M. Atrial fibrillation after surgery of the lung: clinical analysis of risk factors. Eur J Cardiothorac Surg 1998;13:625-8.

17) Lee SH, Ahn HJ, Yeon SM, et al. Potentially modifiable risk factors for atrial fibrillation following lung resection surgery: a retrospective cohort study. Anaesthesia 2016; 71:1424-30.

18) Park BJ, Zhang H, Rusch VW, et al. Video-assisted thoracic surgery does not reduce the incidence of postoperative atrial fibrillation after pulmonary lobectomy. J Thorac Cardiovasc Surg 2007;133:775-9.

19) Riber LP, Larsen TB, Christensen TD. Postoperative atrial fibrillation prophylaxis after lung surgery: systematic review and meta-analysis. Ann Thorac Surg 2014;98:1989-97.

20) Saran T, Perkins GD, Javed MA, et al. Does the prophylactic administration of magnesium sulphate to patients undergoing thoracotomy prevent postoperative supraventricular arrhythmias? A randomized controlled trial. Br J Anaesth 2011;106:785-91.

21) Fairley J, Glassford NJ, Zhang L, et al. Magnesium status and magnesium therapy in critically ill patients: A systematic review. J Crit Care 2015;30:1349-58.

22) Fernando HC, Jaklitsch MT, Walsh GL, et al. The Society of Thoracic Surgeons practice guideline on the prophylaxis and management of atrial fibrillation associated with general thoracic surgery: executive summary. Ann Thorac Surg 2011;92:1144-52.

23) Ciszewski P, Tyczka J, Nadolski J, et al. Comparative efficacy and usefulness of acebutolol and diltiazem for the prevention of atrial fibrillation during perioperative time in patients undergoing pulmonary resection. Thorac
Cardiovasc Surg 2013;61:365-72

24) Aoyama H, Otsuka Y, Aoyama Y. Landiolol infusion during general anesthesia does not prevent postoperative atrial fibrillation in patients undergoing lung resection. Gen Thorac Cardiovasc Surg 2016;64:735-41.

25) Alizade E, Sahin M, Simşek Z, et al. Cilostazol decreases total atrial conduction time in patients with peripheral artery disease. Perfusion 2014;29:265-71.

26) Nojiri T, Yamamoto K, Maeda H, et al. A Double-Blind Placebo-Controlled Study of the Effects of Olprinone, a Specific Phosphodiesterase III Inhibitor, for Preventing Postoperative Atrial Fibrillation in Patients Undergoing Pulmonary Resection for Lung Cancer. Chest 2015;148: 1285-92.

27) Amar D, Zhang H, Heerdt PM, et al. Statin use is associated with a reduction in atrial fibrillation after noncardiac thoracic surgery independent of C-reactive protein. Chest 2005;128:3421-7.

28) Murthy SC, Law S, Whooley BP, et al. Atrial fibrillation after esophagectomy is a marker for postoperative morbidity and mortality. J Thorac Cardiovasc Surg 2003;126:1162-7.

29) Hou JL, Gao K, Li M, et al. Increased N-terminal pro-brain natriuretic peptide level predicts atrial fibrillation after surgery for esophageal carcinoma. World J Gastroenterol 2008;14:2582-5.

30) Stawicki SP, Prosciak MP, Gerlach AT, et al. Atrial fibrillation after esophagectomy: an indicator of postoperative morbidity. Gen Thorac Cardiovasc Surg 2011;59:399-405.

31) Rao VP, Addae-Boateng E, Barua A, et al. Age and neo-adjuvant chemotherapy increase the risk of atrial fibrillation following oesophagectomy. Eur J Cardiothorac Surg 2012;42:438-43.

32) Mc Cormack O, Zaborowski A, King S, et al. New-onset atrial fibrillation post-surgery for esophageal and junctional cancer: incidence, management, and impact on short- and long-term outcomes. Ann Surg 2014;260:772-8.

33) Ojima T, Iwahashi M, Nakamori M, et al. Atrial fibrillation after esophageal cancer surgery: an analysis of 207 consecutive patients. Surg Today 2014;44:839-47.

34) Chin JH, Moon YJ, Jo JY, et al. Association between Postoperatively Developed Atrial Fibrillation and Long-Term Mortality after Esophagectomy in Esophageal Cancer Patients: An Observational Study. PLoS One 2016;11:e0154931.

35) Day RW, Jaroszewski D, Chang YH, et al. Incidence and impact of postoperative atrial fibrillation after minimally invasive esophagectomy. Dis Esophagus 2016;29:583-8.

36) Ma JY, Wang Y, Zhao YF, et al. Atrial fibrillation after surgery for esophageal carcinoma: clinical and prognostic significance. World J Gastroenterol 2006;12:449-52.

37) Amar D, Burt ME, Bains MS, et al. Symptomatic tachydysrhythmias after esophagectomy: incidence and outcome measures. Ann Thorac Surg 1996;61:1506-9.

38) Stippel DL, Taylan C, Schröder W, et al. Supraventricular tachyarrhythmia as early indicator of a complicated course after esophagectomy. Dis Esophagus 2005;18: 267-73.

39) Tisdale JE, Wroblewski HA, Wall DS, et al. A randomized, controlled study of amiodarone for prevention of atrial fibrillation after transthoracic esophagectomy. J Thorac Cardiovasc Surg 2010;140:45-51.

40) Horikoshi Y, Goyagi T, Kudo R, et al. The suppressive effects of landiolol administration on the occurrence of postoperative atrial fibrillation and tachycardia, and 
plasma IL-6 elevation in patients undergoing esophageal surgery: A randomized controlled clinical trial. J Clin Anesth 2017;38:111-6.

41) Ojima T, Nakamori M, Nakamura M, et al. Randomized clinical trial of landiolol hydrochloride for the prevention of atrial fibrillation and postoperative complications after oesophagectomy for cancer. Br J Surg 2017;104:1003-9.

42) 伊達洋至. 肺移植の現況と今後の展望. 臨床麻酔 2016;40: 1359-64.

43) Nielsen TD, Bahnson T, Davis RD, et al. Atrial fibrillation after pulmonary transplant. Chest 2004;126:496-500.

44) Mason DP, Marsh DH, Alster JM, et al. Atrial fibrillation after lung transplantation: timing, risk factors, and treatment. Ann Thorac Surg 2007;84:1878-84.

45) Dizon JM, Chen K, Bacchetta M, et al. A comparison of atrial arrhythmias after heart or double-lung transplantation at a single center: insights into the mechanism of post-operative atrial fibrillation. J Am Coll Cardiol 2009;54:2043-8.

46) Lee G, Wu H, Kalman JM, et al. Atrial fibrillation following lung transplantation: double but not single lung transplant is associated with long-term freedom from paroxysmal atrial fibrillation. Eur Heart J 2010;31:2774-82.

47) Henri C, Giraldeau G, Dorais M, et al. Atrial fibrillation after pulmonary transplantation: incidence, impact on mortality, treatment effectiveness, and risk factors. Circ Arrhythm Electrophysiol 2012;5:61-7.

48) Malik A, Hsu JC, Hoopes C, et al. Elevated pulmonary artery systolic pressures are associated with a lower risk of atrial fibrillation following lung transplantation. J Electrocardiol 2013;46:38-42

49) Magruder JT, Plum W, Crawford TC, et al. Incidence of late atrial fibrillation in bilateral lung versus heart transplants. Asian Cardiovasc Thorac Ann 2016;24:772-8.

50) See VY, Roberts-Thomson KC, Stevenson WG, et al. Atrial arrhythmias after lung transplantation: epidemiology, mechanisms at electrophysiology study, and outcomes. Circ Arrhythm Electrophysiol 2009;2:504-10.

51) Christians KK, Wu B, Quebbeman EJ, et al. Postoperative atrial fibrillation in noncardiothoracic surgical patients.
Am J Surg 2001;182:713-5.

52) Sohn GH, Shin DH, Byun KM, et al. The incidence and predictors of postoperative atrial fibrillation after noncardiothoracic surgery. Korean Circ J 2009;39:100-4.

53) Brathwaite D, Weissman C. The new onset of atrial arrhythmias following major noncardiothoracic surgery is associated with increased mortality. Chest 1998;114: 462-8.

54) Winkel TA, Schouten O, Hoeks SE, et al. Prognosis of transient new-onset atrial fibrillation during vascular surgery. Eur J Vasc Endovasc Surg 2009:38:683-8.

55) Nassoiy SP, Blackwell RH, Kothari AN, et al. New onset postoperative atrial fibrillation predicts long-term cardiovascular events after gastrectomy. Am J Surg 2016;211: $559-64$.

56) Blackwell RH, Ellimoottil C, Bajic P, et al. Postoperative Atrial Fibrillation Predicts Long-Term Cardiovascular Events after Radical Cystectomy. J Urol 2015;194:944-9.

57) Valentine RJ, Rosen SF, Cigarroa JE, et al. The clinical course of new-onset atrial fibrillation after elective aortic operations. J Am Coll Surg 2001;193:499-504.

58) Seguin P, Laviolle B, Maurice A, et al. Atrial fibrillation in trauma patients requiring intensive care. Intensive Care Med 2006;32:398-404.

59) Seguin $P$, Signouret $T$, Laviolle $B$, et al. Incidence and risk factors of atrial fibrillation in a surgical intensive care unit. Crit Care Med 2004;32:722-6.

60) Van Gelder IC, Groenveld HF, Crijns HJ, et al; RACE II Investigators. Lenient versus strict rate control in patients with atrial fibrillation. N Engl J Med 2010;362: 1363-73.

61) Lip GY, Frison L, Halperin JL, et al. Identifying patients at high risk for stroke despite anticoagulation: a comparison of contemporary stroke risk stratification schemes in an anticoagulated atrial fibrillation cohort. Stroke 2010:41:2731-8.

62) Shaver CM, Chen W, Janz DR, et al. Atrial Fibrillation Is an Independent Predictor of Mortality in Critically Ill Patients. Crit Care Med 2015;43:2104-11. 


\section{Abstract}

\section{Postoperative atrial fibrillation in thoracic surgery}

\section{Taisuke Yokota}

Department of Anesthesiology, Dokkyo Medical University Saitama Medical Center

2-1-50 Minamikoshigaya, Koshigaya, Saitama 343-8555, Japan

New-onset atrial fibrillation is a common complication in the intensive care unit. The incidence of postoperative atrial fibrillation (POAF) is high, especially after cardiac surgery. Compared with cardiac surgery, the information on POAF occurring in non-cardiac surgery is not sufficient. In non-cardiac surgery, POAF occurs mainly on the postoperative day 2 , which prolongs hospital stay and increases mortality rate. Medical prophylactic agents may effectively reduce POAF. After POAF onset, rate-control or rhythm-control is used, but it is unknown whether these treatments are truly effective. In perioperative management, the incidence of POAF differs depending on the type of pulmonary resection surgery. Patients taking statins and beta-blockers before the operation should continue to take them, and patients with POAF should take magnesium sulfate when serum magnesium concentration is low. The definition of POAF differs depending on each study, and there are many uncertain points. In this paper, we discuss POAF epidemiology, risk factors, prophylaxes, and treatments mainly for pulmonary resection, esophagectomy, and lung transplantation.

Key words: (1) new-onset atrial fibrillation, (2)postoperative atrial fibrillation, (3)epidemiology, (4) risk factors, (5) noncardiac surgery

J Jpn Soc Intensive Care Med 2018;25:171-7. 